\title{
IFAT '93固体廃棄物・リサイクル関係
}

\section{1. ドイッ（ヨーロッパ）の社会風土}

人間の思考・行動様式は, 風土（地球上の位置に基 づく, 大陸或は島国, 気候・地質・地味・地形・景観 $)$ とこれによる生活手段・様式 : 狩猟（騎馬）民族或は 農耕民族，更には，これと深いかかわりを持つ宗教 (一神教或は多神教) によって規制されることは，周 知の通りである。

ミュンヘン I F A T '93を訪問して，その諸展示は, その国の風土・歴史・文化・民族性に基づく環境問題 との取組み姿勢の反映と受取らねばと気づいたのは, 以下の諸見聞によるあのである。

先ず, 見本市会場が緑溢れる公園を囲んだ, 出展総 面積13万 $\mathrm{m}^{2}$ の25の常設館で国際環境展の名に恥じぬ威 容であった，宿泊したホテルがイザール川に沿った大

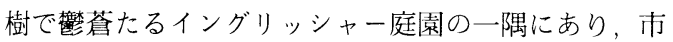
民が庭園内でジョギング・テニスを楽しんでおり日本 のアーバンライフとの差の大きいことを実感, 更にミュ ンヘン近郊の, ロマンティック街道の南端の小旅行を 試みた際，ヒュッセン（Füssen）オーバーアマガウ (Oberammergau) 等の自然を守り, 自然に溶け込 んだ，キリスト教の故事・来歴による諸行事が生きて いる生活を，表面的ではあろうが観祭する機会を持っ たこと等によるものである.

日本の国土は, 人が住み生活の場とし得る面積は約 15\%, 残りは山岳地带であるが，ドイッ（旧西独）は， 南部のアルプス山脈に近い地方を除けば，大部分が平 原と丘陵である.とはいえヨーロッパの中心に位置し， 交通密度は高く人口密度はヨーロッパとしては比較的 高い方である。

日本は, 人口密度はドイッのそれに比べ概算で約 10 倍だが大陸から離れた島国である。火山国の日本は,

*川崎重工業(株)環境装置部

Takeshi SUZUKI, Shin-ichi FUKUMOTO
鈴木武司*・福本真一*

土壤が弱酸性である為, もともと酸性雨に強い樹木が 多い. 降雨量が多く, 河川は急かつ短いから污水は比 較的早く海に流れ希釈される. 地下水の污染も比較的 少ない。

ドイツ（ヨーロッパ）は, 土壤はアルカリ性で, 植 物は本来酸性雨に弱い. 大陸で地続き故, 自国のみな らず周辺国の悪環境をもろに受ける．河川は例えば， ライン : $1,320 \mathrm{~km}$, ドナウ : $2,850 \mathrm{~km}$ (日本の最長, 信 濃川：351km）が数ケ国を時間をかけ，各国の排水・ 污水を取込み, ぶち込まれ, 低降雨量と相俊って, 悪臭と共に, 地下水を污染しながら北海 : 黒海に流れ 込む.

森を知らずにゲルマンを理解出来ないと言われるよ うに，ドイッ人は森の民であり，樹木愛の精神が生き ている，森を散歩するのは生活の一部であり，文学に あ音楽にも，樹木・森が不可欠である．

ドイツ南部の schwarz Wald（黒い森）, Bayerischer Wald（ヴァイエルの森）で代表されるドイッ の森が, 酸性雨・酸性雲の影響で, 特に松や從等の針 葉樹が，50\%以上が被害を受けているのは，緑の党が 躍進し，その後各政党が環境問題を主要政策として取 上げ，後述の厳しい環境法が施行されるに充分すぎる 起爆剤であるのは当然であろう.

ドイツはキリスト教国であり，ドイッ人は所得税の 数（3 ? ）\%を教会税として納めている. 復活信仰に よるものか，遺体は土葬が主である。（あなたは顔に 汗してパンを食べ，ついに土に帰る。あなたは土から 取られたのだから．旧約，創世記 $3-19 ）$ 以前通産省 が計画したシルバーコロンビア計画は，外地で死亡の 際，火葬にして遺骨を日本に持ち帰れないことも一因 で挫折したと記憶している.

後述のドイッ環境法が，ごみの焼却・投棄処理を制 限，再利用・再生を促進せしめているが，これも自然 界の循環を焼却で断ち切らない為であろうか. 勿論燃 
焼による大気污染が動植物他に悪影響を与えかねない のを防ぐことでもあろうが.

\section{2. 環 境 事 情}

\section{（1） ヨーロッパ諸国の環境への取組み}

法律・これを支える環境インフラ整備状況等は跛行 的である。

トップグループ: ドイッ・オランダ・スカンジナビア 諸国・スイス・オーストリア

厳しい法律とこれの実効を図る制度が機能している. セコンドグループ：イギリス・フランス・イタリア

上記グループに追付くベく努力中.

ラストグループ：スペイン・ポルトガル・ギリシャ・

東欧諸国…旧態依然.

トップグループの中でも，ドイッが一番先進的で, 前記の諸事情にもよるが, 論理性・合理性に生きるゲ ルマン気質が，「ごみゼロ社会」を目指して，世界で も一番厳しい環境法を作ると共に，それを遵守可能な らしむるシステムを作り試行錯誤ながら，EC域のモ デルたらんと意気込んでいる。

\section{(2) ドイツ環境法の推移}

(1) 連邦廃棄物除去法（1972年）

収集・処理・眝蔵・埋立という狭義の廃棄物処理が, 環境を損なわずに行われるよう保証することを目標と した。これにより処理・取扱上飛躍的な進歩が見られ たが土壌污染・資源浪費が問題となってきた。

(2) 改正連邦廃棄物法（1986年）

廃棄物の発生の抑制と再利用を，従来の埋立・焼却 処理に優先させた。ただし再利用が技術的・経済的に 可能な場合との条件付きの規定である. 所期の目的達 成のための所要の政令制定権，更に処理のためのガイ ドライン制定の義務を政府に与えている。この政令制 定権に基づき, 有害廃棄物の取扱い, 包装廃棄物の量 の抑制等の規定が可能となった。

（3）包装廃棄物回避のための政令（1991）

家庭・事業所ごみの重量で $1 / 3$, 容量で $1 / 2$ を 占める包装廃棄物につき, 焼却・投棄を禁止し, 再利 用・再資源化を極力実施し，資源の無駄をなくし，環 境保護を図ることを目的としている．そのために，包 装関連業者に包装廃棄物の回収を義務付け上記を実施 せしめる，各業者が独自で実施するとコストが高いの で，法定回収率を達成するなら特殊法人の回収システ ムに加入し，その業務を任せてもよいと決めた。この 業務代行法人がD S D社である。

\section{D S D 社と Green Point}

(1) Dual System Deutchland

\begin{tabular}{|c|c|c|}
\hline \multirow{3}{*}{$\begin{array}{l}\text { Dual } \\
\text { System }\end{array}$} & \multicolumn{2}{|c|}{$\left[\begin{array}{l}\text { 有料…人頭割又はごみ箱の大きさ別．自治 } \\
\text { (焼却用家庭ごみ) } \quad \text { 体が収集・処理を行う. }\end{array}\right.$} \\
\hline & 無料 …G.P印品はD S D & 無料回収し \\
\hline & $\left.\begin{array}{c}(\text { 容器・包装) } \\
\text { 社が，無 } G . P \text { P印品 } \\
\text { は関係業者が }\end{array}\right\}$ & 再和 \\
\hline
\end{tabular}

Dual System を実現するためのD S D 社は, 当初 関連600社で設立したが，現在は9,000社が参加してお り，これは該当社の約75\%であるといわれている．

(2) Green Point: 緑のマーク

D S D 社の加入会社は, 容器・包装に図ー1の緑の マークを表示するが，表示一つ毎にD S D 社に負担金 を支払う。

本年10月 1 日から緑のマーク使用料は, 従来の容量 基準（表 1）加ら重量基準（表 2 ）に変更される。且 つ処理し易いガラス・紙類は割安に, 処理に手数のか かるプラスチック・複合材料は割高になる。これらの 使用料でD S D社は運営費を賄っている。

消費者は, 緑マークごみは人口割で街頭に設置され

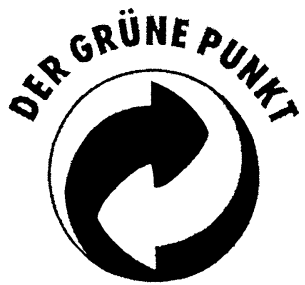

図-1 緑のマーク

表 1 容量別のグリーンポイント使用料 ( $1 \mathrm{DM}=70$ 円)

\begin{tabular}{|c|r|r|}
\hline 包装容器の内容量 & \multicolumn{2}{|c|}{1 個につき } \\
\hline $50 \mathrm{~m} \ell$ 以下 & $0 \mathrm{DM}$ & 0 円 \\
\hline $50 \mathrm{~m} \ell \sim 300 \mathrm{~m} \ell$ & $0.01 \mathrm{DM}$ & 0.7 円 \\
\hline $200 \mathrm{~m} \ell \sim 3 \ell$ & $0.02 \mathrm{DM}$ & 1.4 円 \\
\hline $3 \ell \sim 30 \ell$ & $0.05 \mathrm{DM}$ & 3.5 円 \\
\hline $30 \ell$ 以上 & $0.20 \mathrm{DM}$ & 14.0 円 \\
\hline
\end{tabular}

表 2 素材別重量規準のグリーンポイント使用料 ( $1 \mathrm{DM}=65$ 円 1993.6.17.)

\begin{tabular}{|c|c|c|}
\hline ガ ラ & $0.16 \mathrm{D} \mathrm{M} / \mathrm{kg}$ & 10.4円 $/ \mathrm{kg}$ \\
\hline 紙，カートン & $0.33 \mathrm{DM} / \mathrm{kg}$ & 21.5 円 $/ \mathrm{kg}$ \\
\hline ブリキ，鉄 & $0.56 \mathrm{DM} / \mathrm{kg}$ & $36.4 \mathrm{円} / \mathrm{kg}$ \\
\hline アルミ，他の金属 & $1.00 \mathrm{D} \mathrm{M} / \mathrm{kg}$ & $65.0 \mathrm{PJ} / \mathrm{kg}$ \\
\hline プラスチック & $2.61 \mathrm{DM} / \mathrm{kg}$ & $169.7 \mathrm{M} / \mathrm{kg}$ \\
\hline 複合材料 & $1.66 \mathrm{D} \mathrm{M} / \mathrm{kg}$ & 107.9 円 $/ \mathrm{kg}$ \\
\hline 天然物質 & $0.20 \mathrm{D} \mathrm{M} / \mathrm{kg}$ & 13.0 円 $/ \mathrm{kg}$ \\
\hline
\end{tabular}


ている回収コンテナに分別投入する，DSD社がこれ を定期的に回収し，ドイッ全土で 60 ケ所の集積工場で 詳細分別を主に手作業で行い, 再生実施会社に引渡す。

\section{I F A T '93下水・廃棄物処理，再生技術， 都市清掃，専門見本市}

1) 前述のように, ドイッの環境法は, 固形廃棄物に ついては，「焼却・投棄を抑制し，再利用・再生を促 進することで、「良い環境を守る」ことを目的として いる。これを実現するための諸機器・システムの展示, 即ち緣の下の力持ち・臭いものに蓋をせず合理的に処 理をする，日常人目に触れることは少ないが，これが 機能しない之快適な生活が送れない，将来生存が脅か される，という地味ではあるが不可欠な諸技術展であ る. 出展は(1)下水処理, スラッジ処理・測定制御エン ジニアリング，(2)下水道管渠の清掃・維持管理打よび 補修，(3)廃棄物処理，リサイクリング・都市清掃・道 路サービス・冬季の道路サービス, (4)環境整備技術者 へのサービス・老朽化対策と大別され, 各々専用ビル 或は, 屋外スタンドで展示・実演をやっている.

2) Information Stand が随所にあり，そこで見学 希望技術を告げると（英語不可の場合もあり）, 出展 社名と展示館・小間ナンバーのリストがデータベース より直ちにプリントされる。但し大量に出てくるの で, 結局はシコシコとくま無く迴ることになる。焼却 (Verbrennungs) の例を表 3 に示す.

3) 雾囲気 小間にもよるが, パネル・模型を展示し, カタログ・資料は顧客度に応じて手渡すスタイルが多 かった，技術P Rに一生䯚命のところもあるが，馴染 の客によく来てくれたとビールで歓待, 中には洋酒 （当然ながら）バー䡛みに酒とつまみで歓談するとこ ろもあった。ギ夕一弾き 2 人を動員してお祭騒ぎの小 間ああり，日本の見本市之は大いに異なり，不景気は 何処？上の雾囲気であった。

4) 出展内容の特徴

(1)ごみ処理

焼却が抑制され，DS D社が活躍している所為であ ろうか，6 年前（'87），3 年前（'90）の I F A Tでは 前面に押していたといわれる，焼却とそのガス処理は， パネル・固定模型及びカタログ展示を、スペースはとっ ているものの, ややひっそりやっている感じであった 焼却炉・ガス処理設備 $(\mathrm{HCl}, \mathrm{SOx}$ 除去, 触媒脱硝, バグフィルタ）については，日本技術より進んでいる との印象はなかった。
焼却関係の主要出展は 5 社で, 出展物・資料の内訳 は以下の通りである。

- Deutsche Babcock ; Refuse treatment plants. (1)roller grate (2) moving grate (3)rotary kiln (4)間接加熱ロータリーキルン (5)流動床 (6refuge and sludge composting plant

- THYSSEN ENGINEERING GMBH ‥ MARTIN stoker plnat

○Steag (1)産業・医療廃棄物用ロータリーキルン (2)分別プラント

。A B B ごみ焼却装置用ガス処理設備

。NOEL L (1)ごみ・産廃焼却設備 (2)ガス処理設備 (2) リサイクル関係

これには前処理の分別装置が一番の関心事であるが, 通常の磁選機, ガラス・リサイクルのための色による 分別機 : 実演するも分別率今一つ以外目立った出展 はなかった，DS D社の集積工場でもコンべャの両側 に陣取った人海戦術による分別をやっている。経済的

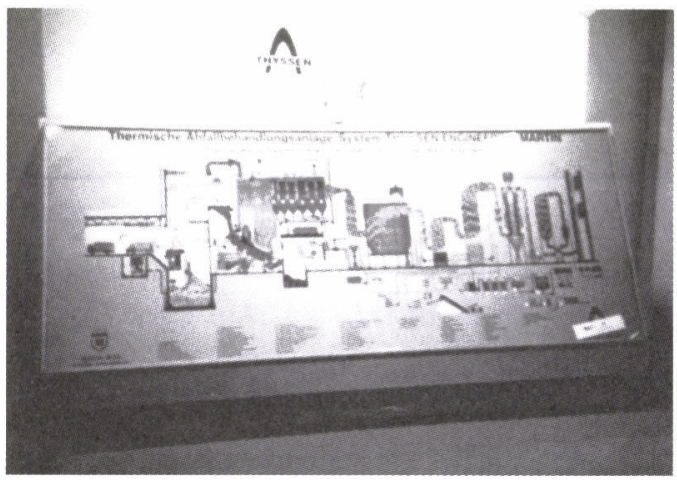

写真 1 T H Y S S E N 社：ごみ焼却プラント

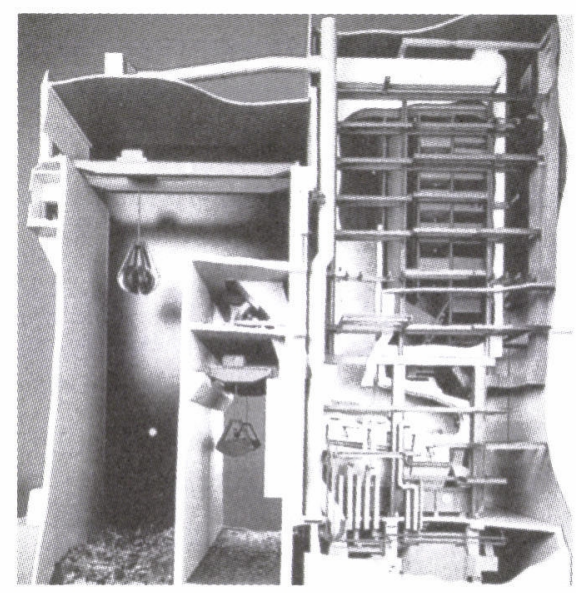

写真 2 NOE L L 社：ごみ焼却プラント 
表 3 出展リスト
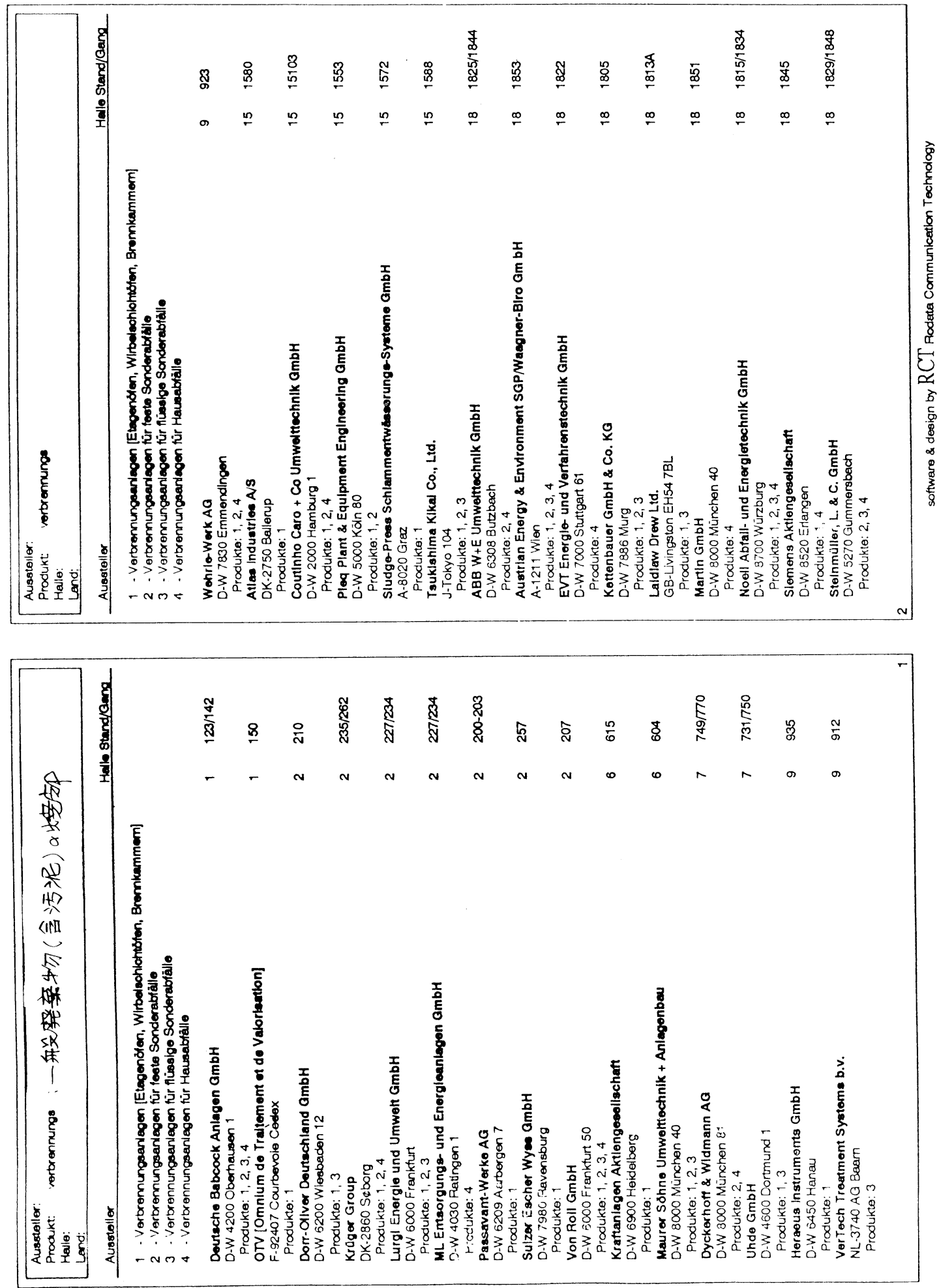
分別は，現在のところこれに勝るものはない由である.

分別されたものの破碎機・減容のためのプレス成形 機は，屋外実演を含め多かったが特段の新メカのもの は見受けなかった，樹木に関心の深いドイッとして， 伐採材の細片化の実演が数種あり, コンポスト材とす る模様であった。

(3) コンポスト

大量処理プラントから, 小型家庭用まで各種取揃え 実機実演も多かった。ドイッでは市民が，シュレーバ ガーデンと称する郊外での小農園を楽しむことが多い ので, 小型機の需要は多いとのことであった。ごみ焼 却場でむコンポスト・ヤードを設けているところがあ る. 日本とは国情が異なるので, コンポストの位置付 けは難しいが生物㳯を元の土に帰えすという自然の循 環を完結せしめる点より一考に值しよう。

(4) 下水道管, 掘削・点検ロボットシステム, 補修 ヨーロッパの都市インフラの基本としての下水道・ 地下共同溝に関する標記の出展は, ビル内外での大型 実車両の展示む含め, 日本では考えられない規模で ある。

。掘削 : 日本の I S E K I が Tunnelling System と して大部の資料を英国現地社より配布し注目をひいて

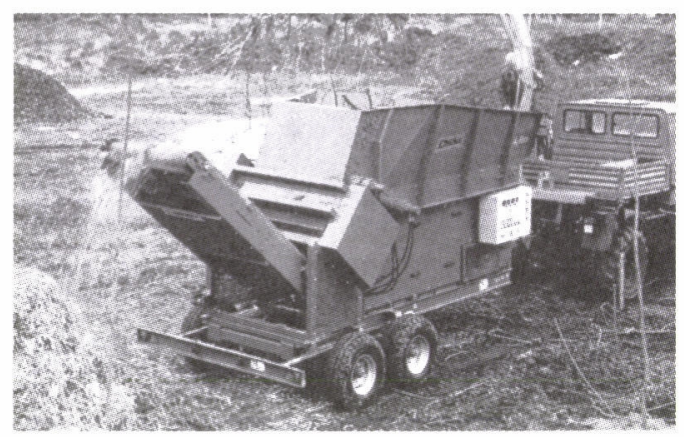

写真 3 L E S C H社：スクリュー式砕木機

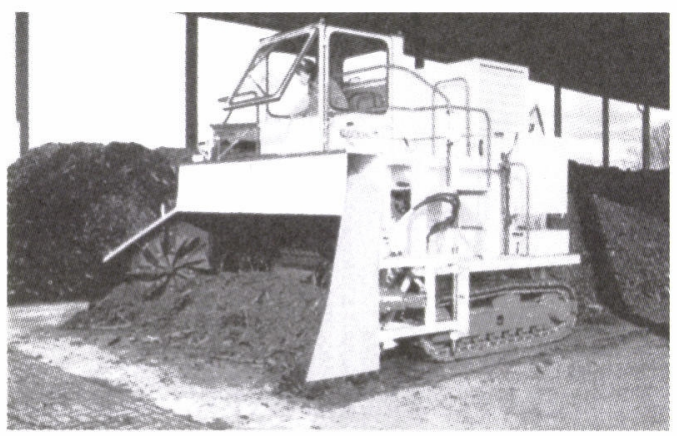

写真 4 B A C K HUS 社: 走行式発酵装置 (コンポスト)
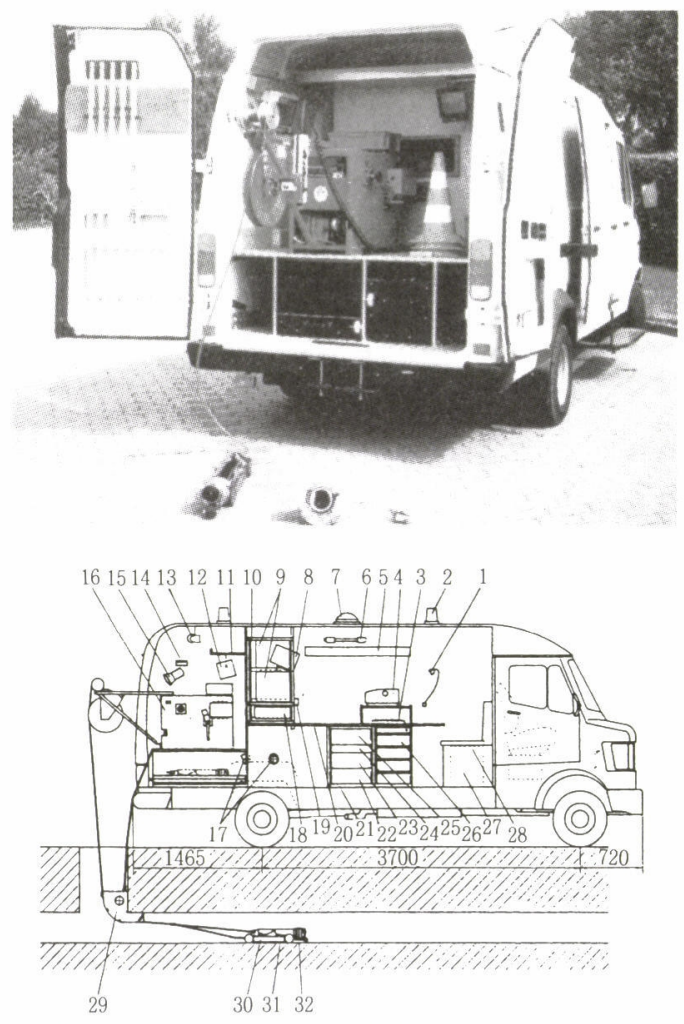

図-2 I B A K 社 : 下水管点検車 (上下共)

いた。

。点検ロボット・下水道漏水部自動補修システム…い ずれも作業用車両内で $T V$ 監視の下に遠隔施工する.

（5）ごみ箱・収集車・道路清掃

前述の諸環境法・包装廃棄物法等上相俊って, D S $\mathrm{D}$ 社の緑のマーク用分別収集用ごみ箱（古瓶一白・緑・ 茶色, 古紙, 容器・包装材用), 家庭用ごみ箱とそれ にマッチした自動取入れ収集車‥これらは取りたてて 目新しいものではないが, 都市計画に基づいた都市構 造に不可分にマッチした回収システムであり，アーバ ンライフの歴史の奥深さが同われる出展である.

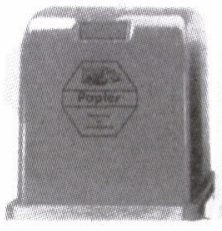

1

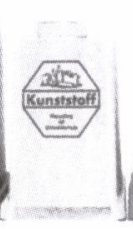

2

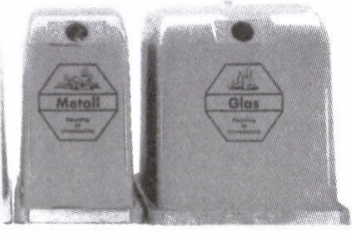

3
4
写真 5 Umwelt technik 社 : リサイクル用回収箱 


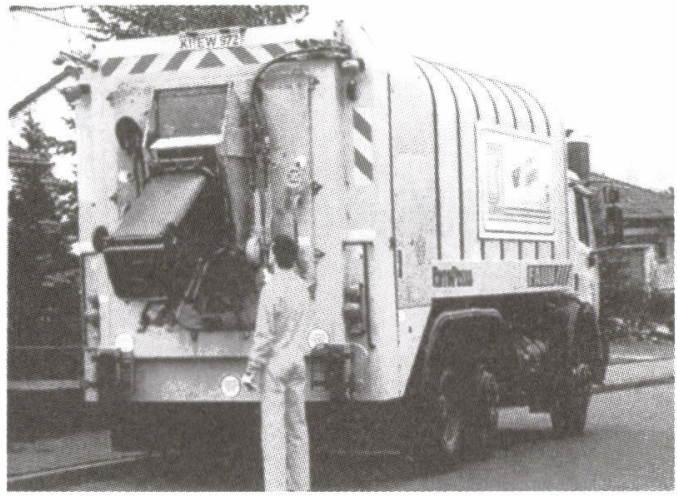

写真 6 Perstorp Norkum 社：ごみ収集車

\section{5.お おりに}

1) 廃衰物の処理については, 法律による規制と, こ れを受取る住民の遵守度の接点が, 現実の姿として目 に映る。これのべースとなるものは，風土・文化・民 族性によるものと解されるが，基本的には

(1) 日本人は，私たちは，良い環境に住む権利があ ると主張。 …公的処理

(2) 北欧人は，私たちは，良い環境を守る義務があ り, 次世代の為に, 多少の犠牲を払うのは当然之 考える、一住民参加

の姿勢の差が反映されているものであろう.

ドイッ人は, 元来節約の精神に富んでいる。‥昔モ ンブランの萬年筆を買った時, 割箸の紙袋的超簡易包
装に驚いた経験があるが, 商品の本質に無関係なむの に金をかけないのは当然であろう.

これとキリスト教精神が結び付き, 循環（サーキュ レーション）による資源の有効活用が図られるのは当 然之，独断的ではあろうが解釈される

最近の地球環境の悪化を実感する諸現象に用まれ， 強力な環境法之, それを遵守するためのシステムとし てのDSD＋緑のマークは, 問題をはらんではいるが ダイナミックに解決に向かって活動している.

2) 現在の日本によって, ドイッの強力な包装法等は 馴染まないかもしれない。しかし, 日本からの輸出品 は,ドイッの港で梱包は外して持帰り, 緑のマークの 梱包に取替えてドイッ国内を流通さしているという現 実がある。ドイッの環境諸法が，EＣに波及し，それ が日本に影響を及ぼすことは当然あり得よう。

資源小国の日本として, 循環に取組むのは当然すぎ ることではある. 地球が小さくなった昨今, 先進的環 境法とこれへの対応の先訓してのドイッの例は，明 日の日本の姿として役立つところ大であろう。

3）技術的な面から彼我の比較をすればデュッセル ドルフのインターパックでの見聞を含め, 焼却関係は 差ないも，埋立技術は日本がきめ細かく進んでいる． 回収システムは, ドイッが断然先進的, リサイクル技 術については，現状差ないも将来的には，D S D 社の 強いニーズに応える新技術の創出が注目される.

いずれも開発力充分な国柄であるので, ニーズに左 右されると言えよう。

\section{ゴミ減量推進イベント “Re-ACTION '93”}

開 催 日 平成 5 年10月23日(土) 24 日(日) 小雨決行

会

主

概

場 久屋大通公園『久屋広場』『光の広場』

催 名古屋市

要 ゴミ減量・資源化の啓発を目的とし た屋外イベント

今年で 4 回目を迎える

〈事業者出展について〉

会場 : 久屋大通公園『久屋広場』

出 展内 容: 各事業者のごみ減量・資源化への取
り組みを紹介

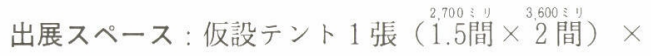
希望テント数

出 展 料: 仮設テント 1 張につき 25,000 円

（電力供給費については、実費とし て5,000円 $/ 1 \mathrm{kVA}$ )

問い合わせ先 名古屋市環境事業局減量推進室

ซ 052 (972) 2397

干460-08 名古屋市中区三の丸 3 丁 目 1 番 1 号 